\title{
Jurnal
}

\section{Hubungan Kualitas Tidur Dengan Kualitas Hidup Pada Lansia Di Surakarta}

\author{
Nur Chasanah ${ }^{1}$, Supratman ${ }^{2 *}$
}

${ }^{1}$ Program Studi Ilmu Keperawatan Universitas Muhammadiyah Surakarta, Kartasura, 57162, Jawa

Tengah, Indonesia.

${ }^{2}$ Departemen Keperawatan Gerontik, Program Studi Ilmu Keperawatan Universitas Muhammadiyah Surakarta, Kartasura, 57162, Jawa Tengah, Indonesia.

*Korespondensi: Sup241@ums.ac.id

\begin{abstract}
Abstrak: Semakin bertambahnya usia, kemungkinan besar seseorang mengalami permasalahn fisik, jiwa, spiritual, ekonomi dan sosial akan semakin tinggi. Salah satu permasalahan yang sangat mendasar pada lanjut usia adalah masalah kesehatan akibat proses degeneratif. Proses degenerasi pada lansia menyebabkan waktu tidur yang efektif semakin berkurang, dan menyebabkan tidak tercapainya kualitas tidur yang adekuat dan menyebabkan berbagi macam keluhan tidur sehingga dapat mengganggu kualitas hidup lansia. Penelitian ini bertujuan untuk mengetahui hubungan kualitas tidur dengan kualitas hidup pada lansia di Surakarta. Penelitian ini adalah penelitian deskriptif korelatif dengan pendekatan cross sectional. Populasi penelitian adalah 334 orang lanjut usia di Surakarta. Sample penelitian sebanyak 96 lansia yang diperoleh dengan teknik proportional random sampling. Penggumpulan data menggunakan kuesioner Pittsburgh Sleep Quality Index (PSQI) dan kuesioner WHOQL-BREF (World Health Organization of Life-BREF), sedangkan analisis data menggunakan uji Chi Square. Hasil uji Chi Square diperoleh p-value sebesar 0,002 sehingga H0 ditolak. Kesimpulan penelitian adalah tingkat kualitas tidur lansia sebagian besar adalah baik, kualitas hidup lansia sebagian besar adalah kurang dan terdapat hubungan tingkat kualitas tidur dengan kualitas hidup lansia di Surakarta dimana semakin baik kualitas tidur lansia maka kualitas hidup lansia semakin tinggi.
\end{abstract}

Kata kunci: lansia, kualitas tidur, kualitas hidup

Abstract: When human get an older, there more likely to experience physical, mental, spiritual, economic and social problems. One of the most basic problems in the elderly is the health problems caused by the degenerative process. The process of degeneration in the elderly causes an effective sleep time decreases, and causes not achieving adequate sleep quality and cause the sharing of sleep complaints that can disrupt the quality of life of the elderly This study aims to determine the relationship quality of sleep with quality of life in elderly in Surakarta. This research is descriptive correlative research with cross sectional approach. The study population was 334 elderly people in Surakarta. The sample of 96 elderly was obtained by proportional random sampling technique. Data collection used the Pittsburgh Sleep Quality Index (PSQI) questionnaire and the WHOQL-BREF (World Health Organization of Life-BREF) questionnaire, while the data analysis used Chi Square test. Chi Square test results p-value of 0.002 so that Hypothetis null was rejected. The conclusion of the study where the level of quality of elderly sleep mostly good, the quality of life of the elderly mostly less and there where correlation level of quality of sleep with quality of life of elderly in Surakarta where better quality of sleep quality of life of elderly higher.

Keywords: elderly, sleep quality, quality of life 


\section{PENDAHULUAN}

Menurut Wordls Health Organization (WHO), orang lanjut usia menurut tingkatan usia lanjut yakni usia pertengahan (45-59), usia lanjut (60-74 tahun), usia lanjut tua (74-84 tahun), usia sangat tua ( $>84$ tahun) (Notoatmodjo, 2007). Indonesia merupakan salah satu negara berkembang dengan jumlah penduduk yang berusia 60 tahun ke atas semakin meningkat dari tahun ke tahun. Hasil sensus penduduk tahun 2010 menunjukkan bahwa Indonesia termasuk dalam lima negara dengan jumlah penduduk lanjut usia terbanyak di dunia, yang mencapai 18,1 juta jiwa atau 7,6\% dari total penduduk. Badan pusat statistik (2013) memproyeksikan jumlah penduduk lanjut usia (60+) diperkirakan akan meningkat menjadi 27,1 juta jiwa pada tahun 2020, menjadi 33,7 juta jiwa pada tahun 2025 dan 48,2 juta jiwa pada tahun 2035 (Kemenkes RI, 2016). Berdasarkan hasil Susenas 2014, jumlah lansia di Indonesia mencapai 20,24 juta orang atau sekitar 8,03\% (Kemenkes RI, 2016)

Menjadi tua merupakan proses yang tidak dapat dihindari oleh setiap individu. Penuaan adalah kondisi yang normal, yang ditandai perubahan fisik dan tingkah laku yang dapat diramalkan dan terjadi pada semua orang saat mereka mencapai usia tahap perkembangan kronologis tertentu (Stanley \& Beare, 2007). Semakin bertambahnya usia, kemungkinan besar seseorang mengalami permasalahn fisik, jiwa, spiritual, ekonomi dan sosial. Salah satu permasalahan yang sangat mendasar pada lanjut usia adalah masalah kesehatan akibat proses degeneratif, hal ini di tunjukkan oleh data pola penyakit pada lanjut usia. Berdasarkan riset kesehatan dasar (Riskesdas) tahun 2013, penyakit terbanyak pada usia lanjut terutama adalah penyakit yang tidak menular antara lain hipertensi (57,6\%), osteo artritis $(51,9 \%)$, stroke $(46,1 \%)$ masalah gigi-mulut $(19,1 \%)$, penyakit paru obstruksi kronis $(8,6 \%)$ dan diabetes mellitus (4,8\%) (KemenkesRI, 2016).

Dari data yang didapat dari Puskesmas Pajang di Kabupaten Surakarta menunjukkan jumlah lansia di wilayah kerja kota surakarta sebanyak 4293. Dari sekian banyak lansia tersebut menunjukkan bahwa kualitas tidur merupakan salah satu faktor masalah kesehatan yang banyak di temui di Puskesmas Pajang dari hasil observasi pada tanggal 10 Oktober 2016 terhadap 5 lansia menunjukkan 3 orang lansia mengalami tidur yang baik yakni mereka tidur mulai jam 8 dan bangun jam 4 dan mereka tidak mengalami masalah tidur seperti sering bangun dimalam hari bahkan insomnia. Sedangkan 2 di antaranya mengalami kualitas tidur yang buruk yakni sering terbangun di malam hari, sulit tertidur atau insomnia serta sering terbangun di malam hari untuk pergi ke kamar mandi. Jumlah kunjungan di bulan Agustus 2016 di Posyandu Melati II - Melati VIII yakni berjumlah 334 orang.

Tidur merupakan salah satu fenomena dasar yang penting bagi kehidupan manusia, kurang lebih dari kehidupan manusia dijalankan dengan tidur. Menurut Hafiza, (2014) proses degenerasi pada lansia menyebabkan waktu tidur yang efektif semakin berkurang, dan menyebabkan tidak tercapainya kualitas tidur yang adekuat dan menyebabkan berbagi macam keluhan tidur. Prevalensi pemenuhan gangguan pemenuhan kebutuhan tidur pada lansia cukup meningkat yaitu sekitar 76\%. Kelompok lansia lebih mengeluh mengalami sulit tidur sebanyak 40\%, sering terbangun pada malam hari sebanyak 30\% dan sisanya gangguan pemenuhan kebutuhan tidur lain (Amir, 2007).

Faktor kebiasaan durasi tidur yang pendek merupakan salah satu faktor yang menyebabkan kualitas tidur yang buruk. Menurut (Komalasari, 2012) dari segi fisik, kurang tidur dapat menyebabkan muka pucat, mata sembab, badan lemas dan daya tahan tubuh menurun sehingga mudah terserang penyakit. Sedangkan dari segi psikis, kurang tidur dapat menyebabkan perubahan suasana kejiwaan, sehingga penderita akan menjadi lesu, lamban menghadapi rangsangan dan sulit berkonsentrasi (Endang, 2007)

Ketidakcukupan kualitas tidur dapat menyebabkan rusaknya memori dan kemampuan kognitif. Apabila hal ini terus berlanjut hingga bertahun-tahun dapat berdampak pada tekanan darah tinggi, stroke, serangan jantung, hingga masalah psikologis serta depresi dan gangguan perasaan lain. Apabila hal ini berlangsung pada waktu yang lama, dapat menyebabkan seseorang mengalami kurang tidur yang mengakibatkan resiko penyakit yang dideritanya (Potter \& Perry, 2012). Faktor usia merupakan faktor terpenting yang berpengaruh terhadap kualitas tidur (Nugroho, 2012).

Menurut Hafiza, (2014) lansia mempunyai kebutuhan yang besar yakni meningkatan kesehatan 
agar dapat hidup sejahtera. Aspek utama peningkatan kesehatan untuk lansia salah satunya adalah dengan memelihara tidur yang efektif untuk proses pemulihan fungsi tubuh sampai tingkat fungsional yang optimal dan untuk memastikan keterjagaan disiang hari guna menyelesaikan tugas sehari-hari dan menikmati kualitas hidup yang tinggi (Stanley \& Beare, 2007).

WHO mengartikan kualitas hidup yaitu sebagai persepsi individu mengenai posisinya dalam kehidupan, dalam konteks kultur dan sistem nilai di mana mereka hidup, dan dalam hubungan dengan tujuan, harapan, standar yang ada, dan perhatian mereka (Pangkahila, 2007). Risdianto, (2009) yang menyebutkan bahwa kesejahteraan menjadi salah satu parameter tingginya kualitas hidup lanjut usia sehingga mereka dapat menikmati kehidupan masa tuanya.

Kualitas tidur baik buruk seseorang terutama pada lansia sangat berkaitan dengan kualitas hidup lansia. Dari kedua keterkaitan variabel tersebut peneliti tertarik untuk melakukan penelitian apakah ada hubungan kualitas tidur dengan kualitas tidur lansia di Kelurahan Karangasem Kec. Laweyan Surakarta. Tujuan penelitian ini adalah untuk mengetahui hubungan kualitas tidur dengan kualitas hidup pada lansia di Kelurahan Karangasem Laweyan Surakarta.

\section{METODE}

Penelitian ini merupakan jenis penelitian kuantitatif dengan metode penelitian deskriptif korelatif yaitu penelitian yang dilakukan untuk mengetahui hubungan antara dua variabel atau lebih, tanpa melakukan perubahan, tambahan, atau manipulasi terhadap data yang memang ada. Penelitian ini menggunakan pendekatan cross-sectional yaitu meneliti suatu populasi referen yang dilakukan sewaktu-waktu atau periode waktu tertentu untuk mengetahui masalah kesehatan atau faktor risiko yang dapat menyebabkan terjadinya masalah kesehatan pada masyarakat (Swarjana, 2016). Rancangan penelitian ini bertujuan untuk mengetahui adanya hubungan antara kualitas tidur dengan kualitas hidup pada lansia di Kelurahan Karangasem Kec. Laweyan Surakarta.

Populasi penelitian adalah 334 orang lanjut usia yang tinggal di desa Karang Asem kecamatan Laweyan. Sampel penelitian sebanyak 96 lansia yang diperoleh dengan teknik proportional random sampling. Penggumpulan data menggunakan kuesioner Pittsburgh Sleep Quality Index (PSQI) dan kuesioner WHOQL-BREF (World Health Organization of Life-BREF), sedangkan analisis data menggunakan uji Chi Square.

\section{HASIL}

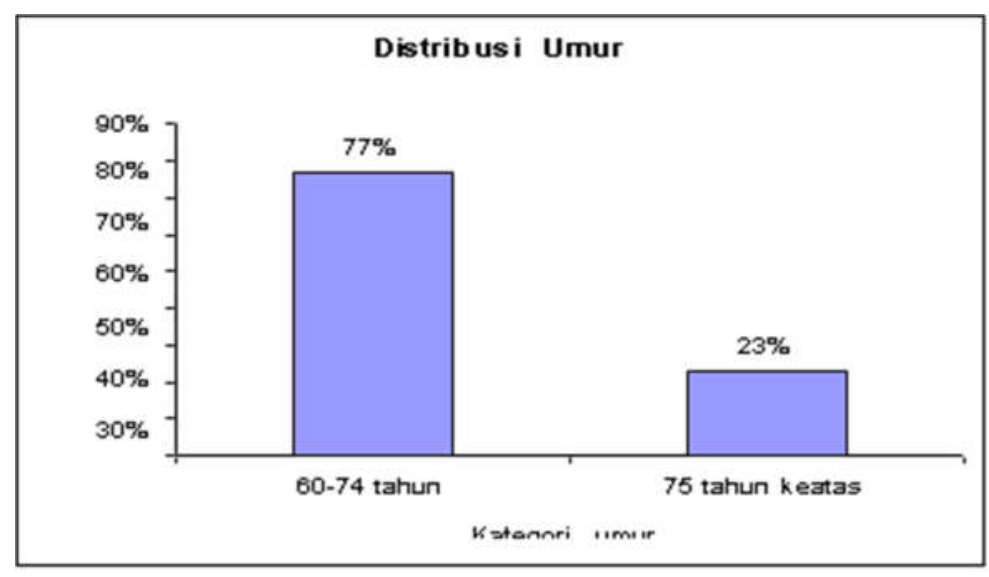

Grafik 1. Distribusi Frekuensi Umur Responden 


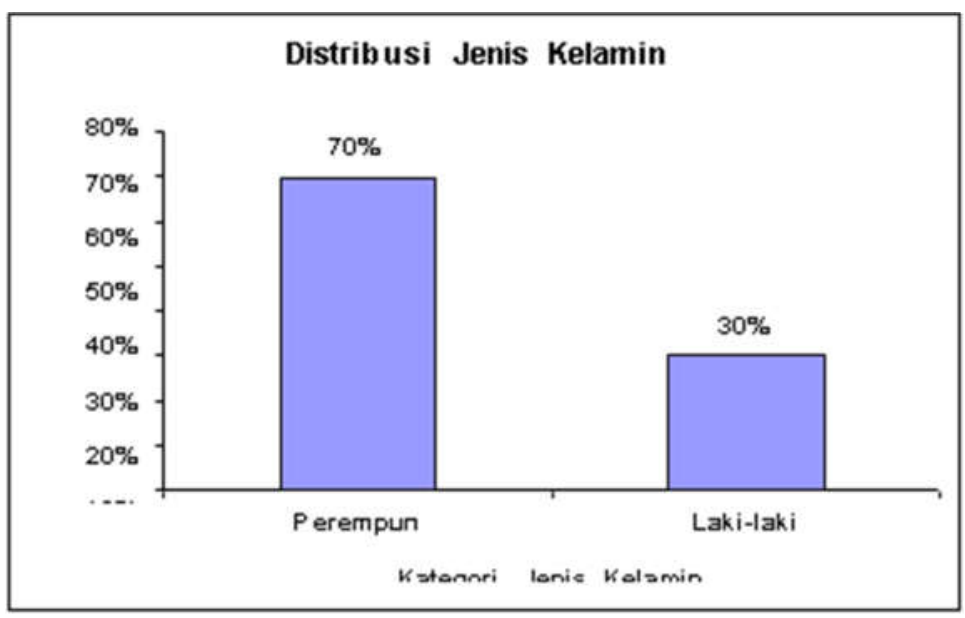

Grafik 2. Distribusi Frekuensi Jenis Kelamin Responden

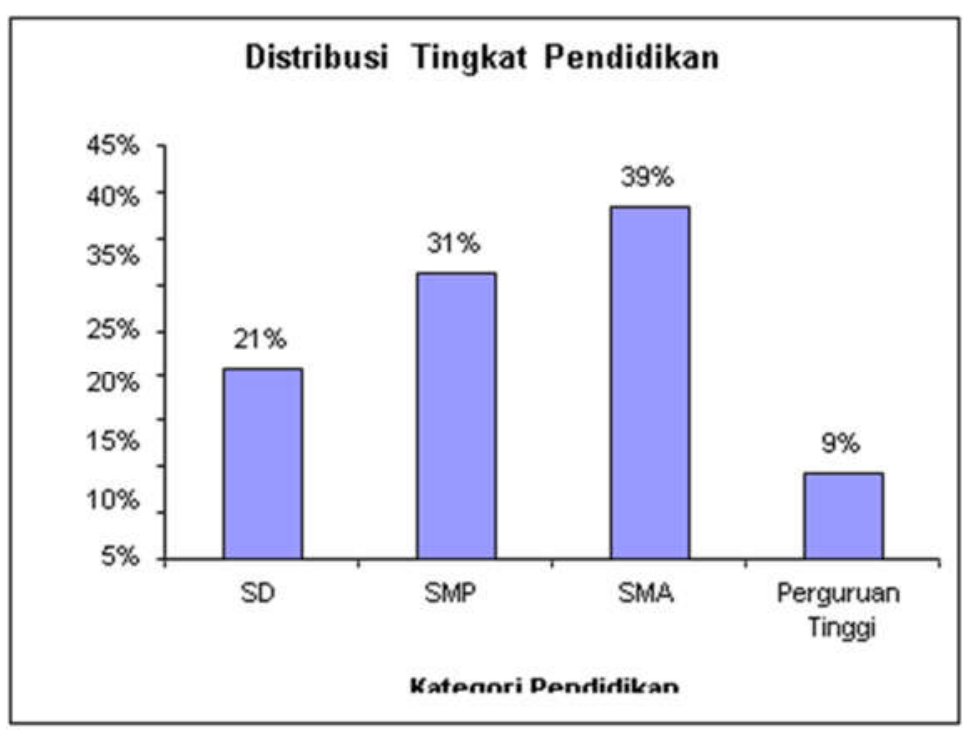

Grafik 3. Distribusi Frekuensi Tingkat Pendidikan Responden

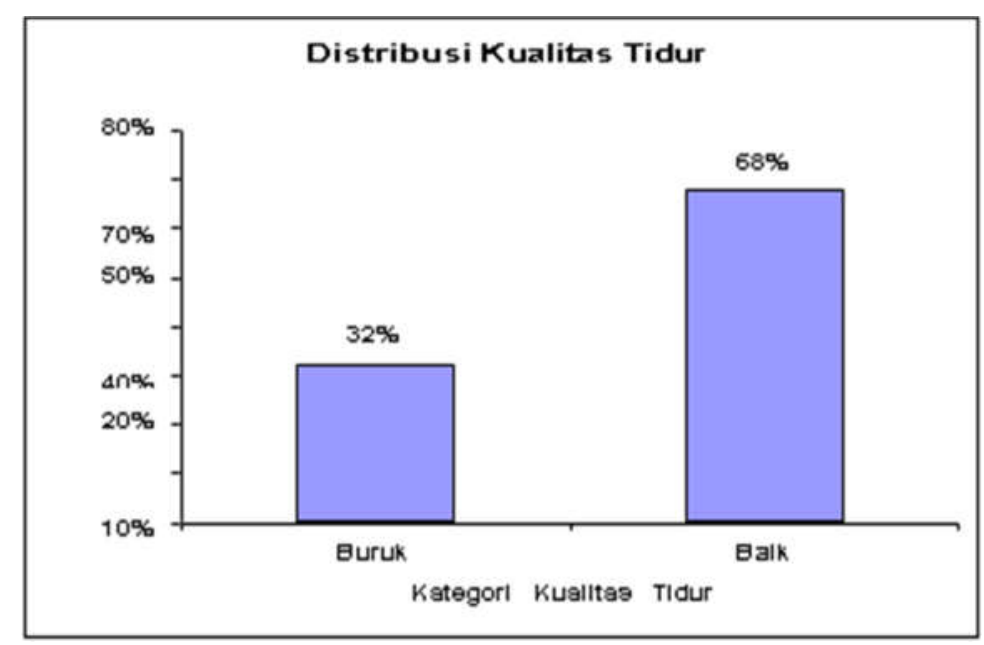

Grafik 4. Distribusi Frekuensi Kualitas Tidur Responden 
Gambaran kualitas tidur lansia diperoleh dari jawaban lansia terhadap 9 item pertanyaan kuesioner yang selanjutnya dibagi dalam tiga kategori kualitas tidur. Distribusi kualitas tidur responden menunjukkan distribusi tertinggi adalah baik yaitu sebanyak 65 responden (68\%) dan sisanya buruk sebanyak 31 responden $(32 \%)$.

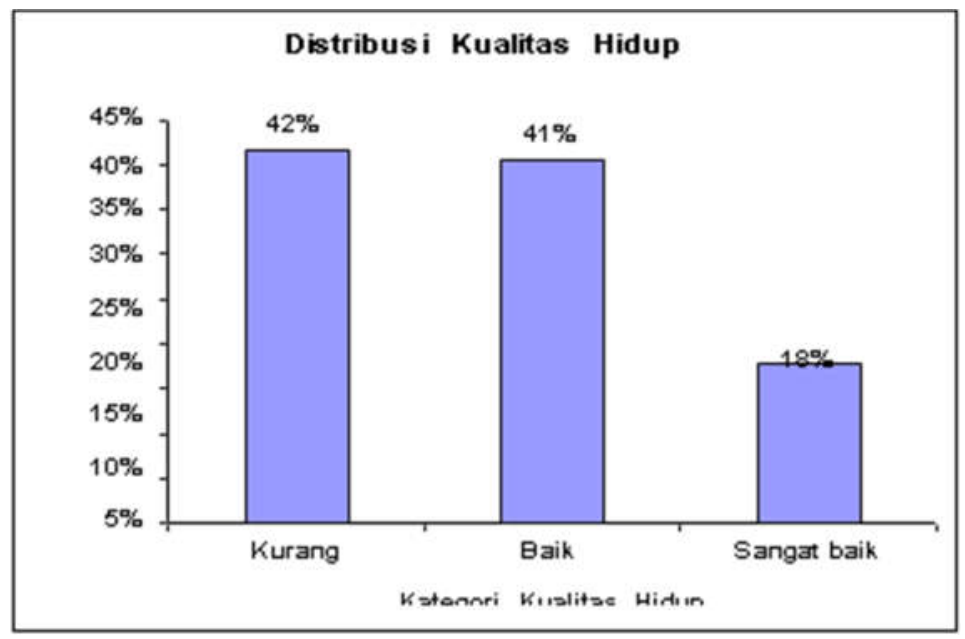

Grafik 5. Distribusi Frekuensi Kualitas Hidup Responden

Gambaran kualitas hidup lansia diperoleh dari jawaban lansia terhadap 26 item pertanyaan kuesioner yang selanjutnya dibagi dalam dua kategori kualitas hidup. Distribusi kualitas hidup responden menunjukkan distribusi tertinggi adalah kurang sebanyak 40 responden (42\%), selanjutnya baik sebanyak 39 responden (40\%), dan sangat baik sebanyak 17 responden (18\%).

Tabel 1. Ringkasan Hasil Uji Chi Square

\begin{tabular}{lllllll}
\hline & Frek & \% & Frek & \% & Frek & \% \\
\hline Buruk & 21 & 68 & 7 & 23 & 3 & 10 \\
Baik & 19 & 29 & 32 & 49 & 14 & 22 \\
Total & 40 & 42 & 39 & 41 & 17 & 18 \\
\hline$\chi^{2}$ & $=12,808$ & & & & & \\
hitung & & & & & & \\
$P$-value & $=0,002$ & & & & & \\
Keputusan uji & $=$ H0 ditolak & & & & & \\
\hline
\end{tabular}

Tabulasi silang hubungan kualitas tidur dengan kualitas hidup lansia menunjukkan bahwa semakin baik kualitas tidur lansia, maka kualitas hidupnya semakin baik.Selanjutnya hasil uji Chi Square diperoleh nilai $\odot 2$ hitung sebesar 12,808 dengan nilai signifikansi ( $p$-value) sebesar 0,002 . Nilai p-value lebih kecil dari 0,05 $(0,002<0,05)$ maka keputusan uji adalah H0 ditolak yang berarti "Ada hubungan kualitas tidurdengan kualitas hidup lansia di desa Karangasem kecamatan Lawean Surakarta" dimana semakin baik kualitas tidur lansia, maka semakin baik pula kualitas hidup lansia.

\section{PEMBAHASAN}

\section{Karakteristik Responden}

Distribusi karakteristik responden menurut usia menunjukkan sebagian besar responden memiliki usia 60-74 tahun keatas. Karakterstik umur responden menunjukkan bahwa sebagian besar responden merupakan kelompok yang sudah mengalami masa degenerasi dimana kemampuan mereka untuk beraktifitas menjadi berkurang. Bertambahnya umur, lansia sudah tidak produktif lagi, kemampuan 
fisik maupun mental mulai menurun, tidak mampu lagi melakukan pekerjaan-pekerjaan yang lebih berat, memasuki masa pensiun, ditinggal mati pasangan, stress menghadapi kematian dan depresi, munculnya berbagai macam penyakit (Flynn, 2013).

Karakteristik jenis kelamin responden menunjukkan distribusi perempuan (70\%). Distribusi jenis kelamin yang sebagian besar perempuan salah satunya disebabkan adanya perbedaan usia harapan hidup laki-laki dan perempuan. Secara teoritis angka harapan hidup wanita lebih tinggi daripada laki-laki sehingga keberadaan lansia perempuan akan lebih banyak daripada lansia laki-laki. Hasil Sensus Penduduk 2010 mencatat angka harapan hidup perempuan sebesar 71,74 tahun, lebih tinggi daripada laki-laki yang sebesar 67,51 tahun. Sesuai dengan teori, maka di Indonesia proporsi lansia perempuan akan lebih tinggi daripada proporsi lansia laki-laki. Hasil Susenas 2014. Proporsi lansia perempuan pada tahun 2014 lebih tinggi 1,11\% dibanding proporsi lansia laki-laki. Baik di perkotaan maupun di perdesaan, proporsi lansia perempuan lebih tinggi dari pada proporsi lansia lakilaki (BPS, 2014).

Distribusi responden menurut pendidikan menunjukkan distribusi tertinggi adalah SMA. Tingkat pendidikan responden menunjukkan bahwa sebagian besar responden berpendidikan rendah, sehingga dapat menghambat kemampuan responden dalam menerima informasi tentang kesehatan. Hal ini sebagaimana dikemukakan oleh Notoatmodjo (2008) bahwa tingkat pendidikan seseorang berpengaruh dalam memberikan respon terhadap sesuatu yang datang dari luar. Menurut Hapsari (2009) presentase penduduk dengan tingkat pendidikan SMA ke atas memiliki status kesehatan baik yang paling banyak jika dibandingkan SD, SMA ataupun yang tidak lulus SD. Dapat dikatakan, penduduk yang tingkat pendidikannya rendah berpeluang 1,7 kali berstatus kesehatan yang kurang baik dibandingkan mereka yang berpendidikan tinggi, sedang yang berpendidikan rata-rata sedang hanya berpeluang 1,2 kali memiliki kesehatan yang buruk dari pada penduduk berpendidikan tinggi. Dapat disimpulkan bahwa, semakin tinggi tingkat pendidikan maka semakin baik status kesehatannya. Sebaliknya makin rendah tingkat pendidikan seseorang maka makin buruk status kesehatannya.

\section{Distribusi Frekuensi Kualitas Tidur}

Distribusi kualitas tidur responden menunjukkan sebagian besar adalah baik. Kebutuhan tidur akan berkurang dengan berlanjutnya usia. Pada usia 12 tahun kebutuhan untuk tidur adalah 9 jam, berkurang menjadi 8 jam pada usia 20 tahun, tujuh jam pada usia 40 tahun, enam setengah jam pada usia 60 tahun, dan enam jam pada usia 80 tahun. Kualitas tidur pada kelompok usia lanjut cenderung mengalami penurunan, pada usia 65 tahun mereka yang tinggal di rumah setengahnya diperkirakan mengalami penurunan kualitas tidur dan dua pertiga dari mereka yang tinggal di tempat perawatan usia lanjut juga mengalami penurunan kualitas tidur. Mereka cenderung susah tidur karena mereka terlalu banyak memikirkan hal - hal yang meresahkan fikiran. Pada usia lanjut tersebut tentunya ingin merasakan tidur enak dan nyaman setiap hari, yang merupakan indikator kebahagiaan dan derajat kualitas hidup. Sedangkan penurunan kualitas tidur dianggap sebagai bentuk paling ringan dari gangguan mental (Dewi, 2015).

Kualitas tidur merupakan masalah klinis yang penting dan luas kompleks. Orang yang terganggu dalam tidur beresiko terjadi kelelahan. Kualitas tidur yang buruk juga terkait dengan fungsi kekebalan tubuh seseorang dan depresi. Obat tidur sering memiliki efek samping yang tidak diinginkan, dalam penelitian ini melalui metode alternatif untuk meningkatkan kualitas tidur pada pasien.Program latihan pada kualitas tidur dapat meningkatkan kualitas hidup. Hasil kami menunjukkan bahwa program latihan berjalan yang dilakukan dirumah dapat memperbaiki kualitas tidur dan kualitas hidup dan bahwa peningkatan kualitas hidup mungkin sebagian dikontribusi oleh tidur (Mei, et al, 2010).

Pola dan kebutuhan tidur lansia adalah sekitar 6 jam setiap malam. Sekitar $20 \%$ sampai $25 \%$ tidur berupa tidur REM. Tidur tahap ke IV menurun dan pada beberapa keadaan tidak terjadi tahap IV. Banyak lansia terbangun di malam hari dan seringkali mereka memerlukan waktu yang lama untuk dapat kembali tidur (Kozier, 2011). 
Proses penuaan membuat lansia lebih mudah mengalami gangguan tidur, selain mengakibatkan perubahan normal pada pola tidur dan istirahat lansia (Maas, 2011). Keluhan-keluhan seputar masalah tidur merupakan masalah umum yang terjadi di masyarakat luas, khususnya pada lansia (Roland, 2011). Frost (2001, dalam Amir, 2007), menyatakan bahwa prevalensi gangguan tidur pada lansia cukup tinggi yaitu sekitar $67 \%$. Lansia seringkali melaporkan mengalami kesulitan untuk dapat tertidur saat berada di tempat tidur. Webb (1989, dalam Maas, 2011), juga menyatakan bahwa penundaan waktu tertidur terjadi pada satu dari tiga lansia wanita dan satu dari lima lansia pria. National Institute of Health Consensus Development Conference pada tahun 1990 menyatakan gangguan tidur menyerang 50\% orang yang berusia 65 tahun yang tinggal di rumah (Maas, 2011).

\section{Distribusi Frekuensi Kualitas hidup Lansia}

Distribusi kualitas hidup responden menunjukkan distribusi tertinggi adalah tinggi (58\%) dan sisanya rendah (42\%). Berdasarkan hasil penelitian ini menunjukkan bahwa persepsi lansia terhadap kondisi dirinya sebagian besar adalah baik.

Dewi (2014) menjelaskan kualitas hidup (quality of life) adalah persepsi pribadi seseorang akan hidupnya berdasarkan nilai dan kepercayaan personal yang mencakup semua area kehidupan seperti komponen lingkungan dan materil, komponen fisik, mental dan sosial.

Dilihat dari usia responden diketahui bahwa lansia dengan usia 60-75 tahun. Secara fisiologis semakin bertambahnya usia seorang individu maka akan mengalami penurunan kondisi fisik. Lansia yang memiliki kondisi fisik yang menurun akan menyebabkan lansia merasa tidak berguna dan tidak menikmati dalam menjalani kehidupannya. Hal tersebut memungkinkan lansia memiliki kualitas hidup yang kurang. Menurut Sutikno (2011) lansia yang berusia 70 tahun ke atas memiliki kemungkinan untuk berkualitas hidup lebih buruk daripada lansia berusia kurang dari 70 tahun. Semakin tua umur semakin buruk kualitas hidup.

Dilihat dari jenis kelamin responden diketahui bahwa lansia dengan jenis kelamin perempuan sebagian besar memiliki kualitas hidup rendah. Secara fisik perempuan dan pria lansia memiliki perbedaan dalam melakukan aktivitas. Selain itu, lansia dengan jenis kelamin perempuan di Kelurahan Karangasem Pajang memiliki nilai yang lebih tinggi dalam hal kesepian dan kekhawatiran terhadap kondisi kesehatannya, sedangkan pada lansia berjenis kelamin laki-laki memiliki kepuasan yang lebih tinggi dalam beberapa aspek yaitu hubungan personal dan kondisi kesehatannya. Perbedaan jenis kelamin dapat mempengaruhi kualitas hidup lansia. Hal ini sesuai dengan penelitian yang dilakukan oleh Pradono et.,al (2009) berdasarkan analisis multivariat logistik regresi yang mengemukakan bahwa perempuan berisiko 1,3 kali memiliki kualitas hidup kurang dibandingkan laki-laki.

\section{Hubungan Kualitas tidur dengan Kualitas Hidup Lansia}

Hasil uji Chi Square disimpulkan ada hubungan kualitas tidur dengan kualitas hidup lansia di kelurahan Karangasem kecamatan Lawean Surakarta, dimana semakin baik kualitas tidur maka kualitas hidup lansia juga semakin baik. Hasil penelitian ini didukung oleh Pereira (2014) yang meneliti hubungan pola tidur dengan kualitas hidup lansia. Penelitian ini menyimpulkan bahwa ada hubungan korelasional pola tidur dengan kualitas hidup lansia.

Menjadi tua merupakan proses yang tidak dapat dihindari oleh setiap individu. Penuaan adalah kondisi yang normal, yang ditandai perubahan fisik dan tingkah laku yang dapat diramalkan dan terjadi pada semua orang saat mereka mencapai usia tahap perkembangan kronologis tertentu (Stanley \& Beare, 2007). Semakin bertambahnya usia, kemungkinan besar seseorang mengalami permasalahn fisik, jiwa, spiritual, ekonomi dan sosial. Salah satu permasalahan yang sangat mendasar pada lanjut usia adalah masalah kesehatan akibat proses degeneratif, hal ini di tunjukkan oleh data pola penyakit pada lanjut usia. Berdasarkan riset kesehatan dasar (riskesdas) tahun 2013, penyakit terbanyak pada usia lanjut terutama adalah penyakit yang tidak menular antara lain hipertensi (57,6\%), osteo artritis $(51,9 \%)$, stroke $(46,1 \%)$ masalah gigi-mulut $(19,1 \%)$, penyakit paru obstruksi kronis $(8,6 \%)$ dan diabetes mellitus (4,8\%) (KemenkesRI, 2016). 
Tidur merupakan salah satu fenomena dasar yang penting bagi kehidupan manusia, kurang lebih dari kehidupan manusia dijalankan dengan tidur. Menurut Hafiza, (2014) proses degenerasi pada lansia menyebabkan waktu tidur yang efektif semakin berkurang, dan menyebabkan tidak tercapainya kualitas tidur yang adekuat dan menyebabkan berbagi macam keluhan tidur. Prevalensi pemenuhan gangguan pemenuhan kebutuhan tidur pada lansia cukup meningkat yaitu sekitar $76 \%$. Kelompok lansia lebih mengeluh mengalami sulit tidur sebanyak $40 \%$, sering terbangun pada malam hari sebanyak 30\% dan sisanya gangguan pemenuhan kebutuhan tidur lain (Amir, 2007).

\section{KESIMPULAN}

Tingkat kualitas tidur lansia di Kelurahan Karangasem Kecamatan Laweyan Surakarta sebagian besar adalah baik. Kualitas hidup lansia di Kelurahan Karangasem Kecamatan Laweyan Surakarta sebagian besar adalah kurang. Terdapat hubungan tingkat kualitas tidur dengan kualitas hidup lansia di Kelurahan Karangasem Kecamatan Laweyan Surakarta dimana semakin baik kualitas tidur lansia maka kualitas hidup lansia semakin tinggi.

Lansia hendaknya senantiasa mengikuti program-program yang direncanangkan oleh pemerintah untuk menjaga kualitas hidup lansia, misalnya kegiatan posyandu lansia. Keaktifan lansia dalam program tersebut diharapkan dapat meningkatkan kualitas hidup lansia dengan terkontrolnya kondisi kesehatan lansia. Keluarga hendaknya memberikan dukungan yang baik kepada lansia seiring dengan penurunan kemampuan dan fisik lansia. Dukungan keluarga yang baik diharapkan dapat menjaga kesehatan lansia baik secara fisik maupun psikis sehingga kualitas hidup lansia dapat terjaga. Petugas kesehatan hendaknya senantiasa melakukan upaya-upaya untuk meningkatkan kualitas hidup lansia, misalnya dengan melakukan pendidikan dan promosi kesehatan kepada lansia dan keluarga lansia agar dukungan terhadap lansia semakin meningkat. Peneliti selanjutnya hendaknya menambahkan faktor-faktor lain yang berhubungan dengan kualitas hidup lansia, misalnya faktor karakteristik lansia, faktor dukungan keluarga dan faktor dukungan masyarakat, sehingga diketahui faktor manakah yang paling dominan berhubungan dengan kualitas hidup lansia.

\section{DAFTAR PUSTAKA}

Adib. M. (2009). Cara Mudah Memahami dan Menghindari Hipertensi Jantung dan Stroke. Yogyakarta : Dianloka

Almatsier, S. (2006). Perinsip Dasar Ilmu Gizi. Jakarta: PT. Gramedia Pustaka Utama.

Arikunto, S. (2013). Prosedur Penelitian: Suatu Pendekatan Praktik. Ed. Revisi 2010. Jakarta: Rineka Cipta.

Arista. (2013). Faktor Yang Berhubungan Dengan Kepatuhan Diit Pasien Hipertensi. Skripsi. Jurusan Ilmu Kesehatan Masyarakat Universitas Negeri semarang.

Austriani. (2008). Risiko Perilaku Perawatan Diri Pasien Hipertensi Terhadap Kejadian Penyakit Jantung Koroner Pada Pasien Hipertensi. Skripsi. Airlangga University Library. Surabaya. http://repository.unair.ac.id/21872/.

Balitbang Kemenkes RI. (2013). Riset Kesehatan Dasar; RISKESDAS. Jakarta: Balitbang Kemenkes RI.

Baradero, M., Wilfrid, D \& Yakobus, S. (2008). Klien Gangguan Kardiovaskular. Jakarta : EGC. Black, M,. Joyce \& Hawks J. H. (2014). Keperawatan Medikal Bedah Edisi 8. Buku 2. Singapore: Elsevier.

Dahlan, M. S. (2011). Statistik untuk kedokteran dan kesehatan. Jakarta: Salemba Medika.

Dewi, K, C, C. (2016). Hubungan Dukungan Keluarga Dengan Tingkat Kepatuhan Penatalaksanaan Diet Lansia Dengan Hipertensi Di Lingkungan Kelurahan Tonja. Jurnal Keperawatan Coping Ners. Edisi Januari-April 2016. Denpasar: Program Studi Ilmu Keperawatan Fakultas Kedokteran Universitas Udayana

Dinkes Jateng. (2013). Profil Kesehatan Provinsi Jawa Tengah Tahun 2013. Semarang: Dinas Kesehatan Provinsi Jawa Tengah.

Dinkes Sukoharjo. (2013). Profil Kesehatan Kabupaten Sukoharjo Tahun 2013. Sukoharjo: Dinas Kesehatan Kabupaten Sukoharjo. 
Hawari, D. (2011). Manajemen Stres, Cemas dan Depresi. Jakarta: Balai FKUI.

Hermanus, M, Z \& Arwam. (2015). Riset kesehatan. Yogyakarta: Ombak.

Hidayat, A \& Aziz, A. (2011). Metode Penelitian Keperawatan dan Teknik Analisis Data. Jakarta: Salemba Medika. (2014). Metode Penelitian Kebidanan dan Teknik Analisis Data. Edisi 2. Jakarta: Salemba Medika.

Imron T, A., Moch \& Munif, A. (2010). Metodologi Penelitian Bidang Kesehatan: Buku Ajar untuk Mahasiswa. Jakarta: Sagung Seto.

Junaidi, I. (2010). Hipertensi. Jakarta: Bhuana Almu Popular.

Kholid, A. (2012). Promosi Kesehatan: Dengan Pendekatan Teori Perilaku, Media dan Aplikasinya. Jakarta : Rajawali Pers.

Laksono, R. A. (2013). Hubungan Antara Stres, Pola Makan Dan Kebiasaan Merokok Dengan Terjadinya Kekambuhan Pada Penderita Hipertensi Di Puskesmas Bendosari Sukoharjo (Doctoral dissertation, Universitas Muhammadiyah Surakarta).

Marliani, L, dkk. (2007). 100 Question \& Answers Hipertensi. Jakarta : PT Elex Media Komputindo, Gramedia.

Maryam, S, dkk. (2008). Mengenal Usia Lanjut Dan Perawatannya. Jakarta: Salemba Medika.

Monalis, A, J, dkk. (2012). Hypertension and atrial fibrillation: diagnostic approach, prevention and treatment. Position paper of theWorking Group'Hypertension Arrhythmias andThrombosis'of the European Society of Hypertension. Journal of Hypertension. Lippincott Williams \& Wilkins.

Muhlisin, M. Abi. (2012). Keperawatan Keluarga. Yogyakarta: Gosyen Publishing.

Mukhtarom, N. (2015). Hubungan Tingkat Pengetahuan Tentang Hipertensi Dengan Kepatuhan Diet Hipertensi Di Posyandu Lansia Di Desa Patukrejomulyo Kecamatan Mirit Kabupaten Kebumen. Skripsi. STIKES Muhammadiyah Gombong).

Notoatmodjo, S. (2010). Ilmu Perilaku Kesehatan. Jakarta: Renika Cipta. (2010). Metode Penelitian Kesehatan. edisi revisi. Jakarta: Rineka Cipta.

Nursalam. (2008). Konsep dan Penerapan Metodologi Penelitian Ilmu Keperawatan. Jakarta : Salemba Medika.

Puteh, M. M., \& Muhlisin, H. A. (2015). Hubungan antara Pengetahuan Keluarga Tentang Diit Hipertensi dengan Kekambuhan Hipertensi pada Lansia di Posyandu Setya Budi Desa Reksosari Kecamatan Suruh Kabupaten Semarang (Skripsi, Universitas Muhammadiyah Surakarta).

Putri, R. A. (2014). Hubungan Antara Tingkat Pengetahuan Tentang Diet Hipertensi Dengan Kejadian Kekambuhan Hipertensi Lansia Di Desa Mancasan Wilayah Kerja Puskesmas I Baki Sukoharjo (Skripsi, Universitas Muhammadiyah Surakarta).

Riduwan dan Akdon. (2010). Rumus dan Data dalam Aplikasi Statistika: untuk Penelitian. Bandung: Alfabeta.

Saam, Zulfan dan Wahyuni, Sri . (2012). Psikologi Keperawatan. Jakarta : Rajawali Pers.

Sastroasmoro, S. (2011). Dasar-Dasar Metodologi Penelitian Klinis. Edisi Ke-4. Jakarta: Sagung Seto.

Sherwood, L. (2010). Human Physiology: From Cell to Systems. $7^{\text {th }}$ Ed. Canada: Yolanda Cassio.

Stockslager, Jaime L dan Liz Schaeffer. (2007). Asuhan Keperawatan Geriatrik. Edisi 2. Jakarta: EGC.

Sudoyo, A,W,. Setiyohadi, B,. Alwi, I,. Simadibrata, M,. Setiati, S. (2009). Buku Ajar Ilmu Penyakit Dalam Jilid II. Edisi V. Jakarta: Interna Publishing.

Sugiyono. (2015). Metode Penelitian Dan Pengembangan (Research and Development/RED). Bandung: Alfabeta.

Sulastri, S. (2016). Hubungan antara Stres dan Riwayat Kontrol dengan Kekambuhan Hipertensi pada Lansia di UPTD PSLU Natar Lampung Selatan. Jurnal Kesehatan, 6(2). Diambil dari http://ejurnal.poltekkes- tjk.ac.id/index.php/JK/article/view/88/80

Sunaryo. (2013). Psikologi Untuk Keperawatan, Edisi 2. Jakarta : EGC.

Susila dan Suyanto. (2015). Metodologi Penelitian Cross Sectional Kedokteran dan Kesehatan. Klaten: Bosscript.

Wibowo, A. (2014). Metodologi Penelitian Praktis : Bidang Kesehatan. Jakarta: Rajawali. 